\title{
Chemically induced strong cellular hypertrophy often reduces the accuracy of cytotoxicity measurements obtained using the ATP assay
}

\author{
Haruna Tahara, Yusuke Yamamoto, Shun Matsuda, Hiroe Yoshizawa, Masaharu Fujita, \\ Takanori Hioki and Toshihiko Kasahara
}

Safety Evaluation Center, Fujifilm Corporation, 210 Nakanuma, Minamiashigara-shi, Kanagawa 250-0193, Japan

(Received September 2, 2016; Accepted January 12, 2017)

\begin{abstract}
The ATP assay is a highly sensitive and versatile method for measuring cytotoxicity. However, the correlation between the cell viability results obtained using the ATP assay and those obtained using direct cell counting has not been widely reported. Therefore, to evaluate the reliability and limitations of the ATP assay, we compared the results of ATP assay with those of automatic cell counter, which can measure the number and diameter of cells directly, by using 24 compounds and repeating individual experiments thrice. The correlation between the data was low for 7 of the 24 compounds $\left(r^{2}<0.8\right.$, at least 2 out of 3 experiments). These were the top 7 of the 11 compounds that induced cell hypertrophy. These 7 compounds were also observed to increase the area of mitochondria. However, the last 4 of the 11 compounds increased the cell size but did not increase the mitochondrial area. For the remaining 13 compounds, which had no effect on cell size, a good correlation was observed between the results of the two methods ( $r^{2}>0.8$, at least 2 out of 3 experiments), and the cell size was effectively the same as that of the controls. We concluded that the poor correlation between the two methods was attributable to an increase in the content of intracellular ATP because of the chemically induced cell and mitochondrial hypertrophy. We showed that the ATP assay is unsuitable for assessing the cytotoxicity of compounds that induce cell hypertrophy with increase in the mitochondrial area and ATP content.
\end{abstract}

Key words: ATP assay, Cell hypertrophy, Cytotoxicity test

\section{INTRODUCTION}

Many cytotoxicity assessment methods have been developed to examine the viability and proliferation of cultured cells in the presence of various chemicals (Cook and Mitchell, 1989). Of the various cytotoxicity assays reported in the literature, the ATP assay is the easiest to perform and least time consuming, unlike assays such as the 3-(4,5-dimethylthiazol-2-yl)-2,5-diphenyltetrazolium bromide (MTT) assay and neutral red uptake (NRU) assay, which require cellular uptake of substrates. Therefore, the ATP assay has been used widely for assessing cell viability.

The ATP assay uses bioluminescence as an indicator of the number of living cells. It is a simple, rapid, and sensitive cytotoxicity test (Kuzmits et al., 1986). The ATP assay can be used to evaluate the functional integrity of living cells, since all cells need ATP for cellular functions. The
ATP assay is especially useful, since its application is not limited to cancer cell lines (Augustine et al., 2007), and has a 100-fold higher sensitivity than that of the 3-(4,5dimethylthiazol-2-yl)-5-(3-carboxymethoxyphenyl)-2(4-sulfophenyl)-2H-tetrazolium (MTS) assay for counting the number of cells (Hunter et al., 1993; Petty et al., 1995). It has shown excellent linearity and a wide dynamic range (0-750,000 RLU) in RPMI-8226 cells (Sekhon et al., 2008). Furthermore, a major advantage of the ATP assay over other microplate-based cytotoxicity tests is that the ATP assay can be used to assess cytotoxicity in cell suspensions and monolayers (Kemp et al., 1985). Therefore, the ATP assay has been utilized as cytotoxicity test coupled with chromosome aberration test (Armstrong et al., 1992). The high sensitivity, absence of artifacts, versatility, speed, and simplicity of the ATP assay make it a highly recommended, routine cytotoxicity test (Castaño and Tarazona, 1994).

Correspondence: Toshihiko Kasahara (E-mail: toshihiko.kasahara@fujifilm.com) 


\section{H. Tahara et al.}

Chan et al. (2013) demonstrated that drug-induced increases in ATP content were associated with increase in cell size, by measuring the number and area of cells using a simple high-content imaging method. However, this method was not compared with the traditional method of directly measuring suspended cells, for ensuring accuracy. Especially, since this method measured the area of elongating cells adhering to the plate in two dimensions, the size of the cells measured using this method might be not accurate, unlike measuring the size of cells suspended by enzyme treatment. Therefore, in this study, the number and diameter of cells suspended by enzyme treatment were measured by automatic cell counter in three dimensions. We considered these values as standard and evaluated the accuracy of ATP assay in cells treated with 24 different compounds.

\section{MATERIALS AND METHODS}

\section{Cells and test materials}

CHL/IU (Chinese hamster lung) cells were purchased from DS Pharma Biomedical Co., Ltd. (Osaka, Japan) and maintained in minimum essential medium (MEM; Life Technologies Corporation, Carlsbad, CA, USA) supplemented with $10 \%$ calf serum (Life Technologies) in a humidified incubator at $37^{\circ} \mathrm{C}$ in an atmosphere of $5 \%$ $\mathrm{CO}_{2}$ in air. The 24 compounds used in this study and their suppliers are listed in Table 1.

\section{Test chemical treatment and microplate preparation}

Cells $\left(4 \times 10^{4}\right)$ were seeded in $1 \mathrm{~mL}$ medium in a 12 -well plate and pre-cultured for $24 \mathrm{hr}$ before exposure to the compounds. To prepare the stock solutions for the subsequent preparation of serial dilution solutions, test compounds were dissolved in dimethyl sulfoxide (DMSO) or water at 200 times the final highest concentration (solvents are listed in Table 1). The stock solution was then diluted two-fold or three-fold with solvent in a stepwise manner. Medium containing the diluted compounds was prepared by adding $30 \mu \mathrm{L}$ of the compound solution to $2.97 \mathrm{~mL}$ fresh medium (1\%). The concentrations of the compounds dissolved in the medium were double the desired final concentrations. After pre-culture for $24 \mathrm{hr}$,

Table 1. Compounds tested.

\begin{tabular}{|c|c|c|c|c|}
\hline No & Compound & CAS No. & Manufacturer $^{\mathrm{a}}$ & Solvent \\
\hline 1 & Acetaminophen & $103-90-2$ & Sigma-Aldrich & DMSO \\
\hline 2 & Catechol & $120-80-9$ & TCI & DMSO \\
\hline 3 & $m$-Chloroaniline & $108-42-9$ & Wako & DMSO \\
\hline 4 & Colchicine & $64-86-8$ & Sigma-Aldrich & DMSO \\
\hline 5 & Diethylstilbestrol & $56-53-1$ & Sigma-Aldrich & DMSO \\
\hline 6 & 5-Fluorouracil & $51-21-8$ & Wako & DMSO \\
\hline 7 & 4-Iodoaniline & $540-37-4$ & Sigma-Aldrich & DMSO \\
\hline 8 & 4,4'-Methylenebis (2-chloroaniline) & $101-14-4$ & Wako & DMSO \\
\hline 9 & Methyl methanesulfonate & $66-27-3$ & Wako & DMSO \\
\hline 10 & 2-Methyl-4-nitroaniline & $99-52-5$ & Wako & DMSO \\
\hline 11 & Phenacetin & $62-44-2$ & Wako & DMSO \\
\hline 12 & p-Phenylenediamine & $106-50-3$ & TCI & DMSO \\
\hline 13 & Carmustine & $154-93-8$ & Sigma-Aldrich & DMSO \\
\hline 14 & Cycloheximide & $66-81-9$ & Sigma-Aldrich & DMSO \\
\hline 15 & Daunorubicin & $23541-50-6$ & Wako & DMSO \\
\hline 16 & Doxorubicin & $25316-40-9$ & Wako & DMSO \\
\hline 17 & Rotenone & $83-79-4$ & Sigma-Aldrich & DMSO \\
\hline 18 & Sodium dodecyl sulfate & $151-21-3$ & Sigma-Aldrich & DW \\
\hline 19 & Thioguanine & $154-42-7$ & Wako & DMSO \\
\hline 20 & Amitriptyline $\mathrm{HCl}$ & $549-18-8$ & Sigma-Aldrich & DMSO \\
\hline 21 & Copper sulfate & $7758-98-7$ & Wako & DW \\
\hline 22 & Ferrous sulfate & $7782-63-0$ & Wako & DW \\
\hline 23 & Nicotine & $54-11-5$ & Nacalai Tesque & DMSO \\
\hline 24 & Warfarin & $81-81-2$ & Fluka & DMSO \\
\hline
\end{tabular}

DMSO: Dimethyl sulfoxide; DW: Distilled water

Sigma-Aldrich, Sigma-Aldrich Corporation, St. Louis, MO, USA; TCI, Tokyo Chemical Industry Co. Ltd., Tokyo, Japan; Wako, Wako Pure Chemical Industries Ltd., Osaka, Japan; Nacalai Tesque, Inc., Kyoto, Japan; Fluka, Fluka Ltd., Buchs, Switzerland. 
Effect of chemically induced cellular hypertrophy on ATP assay

a portion of the supernatant in each well $(500 \mu \mathrm{L})$ was discarded, medium $(500 \mu \mathrm{L})$ containing various test compounds at serial two-fold dilutions was added, and the incubation was continued for additional $24 \mathrm{hr}$. Treatment media included $0.5 \%$ solvent in addition to the test compounds. All incubations were carried out in a humidified, $5 \% \mathrm{CO}_{2}$ atmosphere at $37^{\circ} \mathrm{C}$. After incubation, cytotoxicity and cell diameter were evaluated using ATP assay and automatic cell counter. Briefly, the culture medium was removed, the attached cells were rinsed with saline (Hikari Pharmaceutical Co., Ltd., Tokyo, Japan), and $0.4 \mathrm{~mL}$ of pre-warmed $0.25 \%$ trypsin solution (Life Technologies) was added. After incubation at $37^{\circ} \mathrm{C}$ for about $10 \mathrm{~min}$, the cells were collected by pipetting, and transferred to a tube containing fresh medium $(0.4 \mathrm{~mL})$. This cell suspension was used for cytotoxicity testing by the ATP assay and measuring the cell number and the cell diameter using automatic cell counter.

\section{Automatic cell counter}

Cell suspension $(500 \mu \mathrm{L})$ was transferred to cuvettes containing Isoton II Diluent $(9.5 \mathrm{~mL}$; Beckman Coulter, Brea, CA, USA). The number and mean diameter of the cells were determined using a Z2 Coulter Counter (Beckman Coulter).

\section{ATP assay}

Intracellular ATP was quantified using a CellTiter-Glo Luminescent Cell Viability Assay kit (Promega Corporation, Madison, WI, USA). Cell suspension $(100 \mu \mathrm{L})$ was transferred to the wells of a white 96-well microplate (Nunc, Roskilde, Denmark) and CellTiterGlo reagent $(100 \mu \mathrm{L})$ was added. The plate was shaken using a plate shaker for $10 \mathrm{~min}$, and luminescence was measured using Varioskan Flash Microplate Multimode Readers (Thermo Fisher Scientific, Waltham, MA, USA). Cell viability was calculated using the ratio of the luminescence of treated cells to that of control cells, and the data were expressed as percentages.

\section{Measurement of mitochondrial area using an image analyzer}

MitoTracker is a mitochondria-specific fluorescent probe used to assess mitochondrial location, area, and morphological changes (Moon et al., 2013; Okuda et al., 2011). This was the probe used in this study to measure mitochondrial area.

Since the area of a well in a 96-well microplate used in this experiment is about one-tenth that of a well in a 12 -well plate, the cell number and medium volume was assumed to be $1 / 10$ that of the above-mentioned cyto- toxicity test. Cells $\left(4 \times 10^{3}\right)$ were seeded with medium $(100 \mu \mathrm{L})$ in each well with clear bottom as well as in black 96-well microplates and pre-cultured for $24 \mathrm{hr}$ before adding the test compounds. For preparing dilution series of the compounds, the compound solution was diluted with solvents in a 96-well microplate, in a stepwise manner as described above. Medium $(297 \mu \mathrm{L})$ was added to the microplate containing the diluted compounds $(3 \mu \mathrm{L})$, and serial dilutions of the compounds in medium were prepared (compound preparation plates). In the compound preparation plates, the concentrations of the compounds dissolved in the medium were double the desired final concentrations. After pre-culture for $24 \mathrm{hr}$, a portion of the supernatant in each well $(50 \mu \mathrm{L})$ was discarded, and medium $(50 \mu \mathrm{L})$ containing various test compounds at serial two-fold dilutions was transferred to the cell culture microplates. All incubations were carried out in a humidified, $5 \% \mathrm{CO}_{2}$ atmosphere at $37^{\circ} \mathrm{C}$. After incubation for $24 \mathrm{hr}$, the cells were stained with MitoTracker green (Life Technologies), without fixing the cells, to measure mitochondrial area. For double staining of the cells, 10x staining solution was added to the suspension. Twenty micromolar MitoTracker green and $50 \mu \mathrm{M}$ Hoechst 33342 (Life Technologies) in PBS $(10 \mu \mathrm{L})$ were added to the cells, and incubated for $30 \mathrm{~min}$ in a humidified, $5 \% \mathrm{CO}_{2}$ atmosphere at $37^{\circ} \mathrm{C}$. MitoTracker green was used to stain mitochondria and Hoechst 33342 was used to stain the nuclei. Cells were washed once with PBS, and Hank's balanced salt solution (+) $(100 \mu \mathrm{L}$; Wako) was added to develop fluorescence. The bright field and fluorescence images of cells stained with MitoTracker green (Ex: 490 nm, Em: 516 nm) and Hoechst 33342 (Ex: 350 nm, Em: $461 \mathrm{~nm}$ ) were acquired with an IN Cell Analyzer 2000 (GE Healthcare, Little chalfont, Bucks, UK) using a 20x objective lens. The images were analyzed using IN Cell Developer Toolbox software (GE Healthcare). Images of more than 2000 cells or 12 fields per well were acquired and analyzed. Mean cell area was analyzed using bright field images. The mean mitochondrial area was analyzed using MitoTracker green-stained images. The results are presented as the ratio to control treated with solvent alone. For the 7 compounds that induced an increase in the cell diameter, a representative photograph was taken by the IN Cell Analyzer.

\section{Statistical analysis}

The cell diameter in Table 2 and, cell area and mitochondria in Table 3, were compared between compound treated cells and those of the negative control by Dunnett's multiple comparison test. We regarded a result as statistically significant when the $p$-value was 0.01 . 


\section{RESULTS}

\section{Changes in the number and diameter of cells following treatment with $\mathbf{2 4}$ compounds}

Cells treated with 24 compounds in 12-well plates were suspended by trypsinization and the number and diameter of the suspended cells were measured by automatic cell counter. Data from 3 wells per dose per compound were presented as the mean value of one experiment and the mean from three experiments is presented as mean \pm S.D. (Table 2). The correlation between the results of the ATP assay and automatic cell counter was low ( $r^{2}<0.8$, at least 2 out of 3 experiments) in the case of 7 out of the 24 compounds. These 7 compounds are acetaminophen, catechol, 5-fluorouracil, $p$-phenylenediamine, daunorubicin, doxorubicin, and rotenone (Table 2 and Fig. 1). As far as cell size was concerned, we judged the compounds that induced $\geqq 1$.16-fold greater in cell diameter, as having the potency to induce strong cellular hypertrophy. Eleven compounds were found to induce cellular hypertrophy. These compounds, in descending order of the induced increase in diameter, at each of the tested doses are daunorubicin, doxorubicin, acetaminophen, $p$-phenylenediamine, catechol, rotenone, 5-fluorouracil, nicotine, colchicines, 2-methyl-4-nitroaniline, and methyl methanesulfonate.

\section{Measurement of intracellular mitochondrial area}

To evaluate the relationship between cell hypertrophy and intracellular ATP content, we measured the area of mitochondria in cells treated with the 24 compounds. We stained the mitochondria and nuclei by using specific fluorescent dyes MitoTracker and Hoechst 33342, respectively. We used an image analyzer for calculating the mitochondrial area and the total cell area. The results of this experiment are shown in Table 3. Among 11 compounds that induced an increase in cell diameter, 7 compounds were observed to significantly increase the area of intracellular mitochondria. These compounds are acetaminophen, catechol, 5-fluorouracil, $p$-phenylenediamine, daunorubicin, doxorubicin and rotenone. These 7 compounds were the same as those with which, the correlation between the results of the ATP assay and automatic cell counter was low ( $r^{2}<0.8$, at least 2 out of 3 experiments). The other 4 compounds which did not induce increase in the area of intracellular mitochondria were colchicine, methyl methanesulfonate, 2-methyl-4-nitroaniline and nicotine. There was good correlation between the results of the two methods in all three experiments $\left(r^{2}>0.8\right.$, at least 2 out of 3 experiments) in the presence of these 4 compounds. As shown in the photograph (Fig. 2), these 7 compounds obviously induced hypertrophy in the cells.

\section{DISCUSSION}

To evaluate the reliability and limitations of the ATP assay for assessing cytotoxicity, we assayed cytotoxicity of 24 compounds by both the ATP assay and automatic cell counter. Individual experiments were repeated thrice to ensure reliability and reproducibility. Since the automatic cell coulter can accurately measure the number and diameter of individual cells, we considered the values derived from automatic cell counter as the standards. Because the ATP assay is often used to evaluate cytotoxicity in an in vitro mammalian cell genotoxicity test, 12 of the compounds used in this study were those reported by Matsushima et al. (1999) to possess various genotoxic properties. In addition, 7 compounds were selected from a report that established drug cytotoxicity (Evans et al., 2001), and 5 compounds were selected from a report based on a multicenter evaluation of in vitro cytotoxicity (MEIC) (Bondesson et al., 1989). Because sensitivity to cytotoxicity may be changed by cell density, we confirmed that the doubling time of the control cells corresponds to the logarithmic growth phase of CHL cells during drug treatment in this experiment. Cells were exposed to the compounds for $24 \mathrm{hr}$ and then trypsinized before assaying. We assessed the correlation between the cell viability values obtained using the two methods. Seven compounds were identified, where the correlation between the two sets of results was low $\left(r^{2}<0.8\right.$, at least 2 out of 3 experiments), and further experiments indicated that this was attributable to an increase in intracellular ATP with strong cell hypertrophy. Though 11 compounds that included the above 7 compounds were confirmed to induce hypertrophy, the top seven of the 11 compounds which increased the cell size were found to increase cellular ATP content with increasing area of mitochondria, and the remaining 4 compounds increased neither the ATP content nor the area of mitochondria. Furthermore, we observed that compounds possessing the strongest potential to induce cell hypertrophy, induced increase in cellular ATP content and area of mitochondria. When the correlation between the cell viability results obtained using the ATP assay and those obtained using direct cell counting is low, the cell diameter is $\geqq 1.16$-fold greater than that of the control. Therefore, the case where the cell is hypertrophied more than this value was defined as "strong cellular hypertrophy".

Six of the 7 compounds that induced cell hypertrophy and increased the intracellular ATP content in this study, had been reported to be genotoxic and clastogenic. These 
Effect of chemically induced cellular hypertrophy on ATP assay
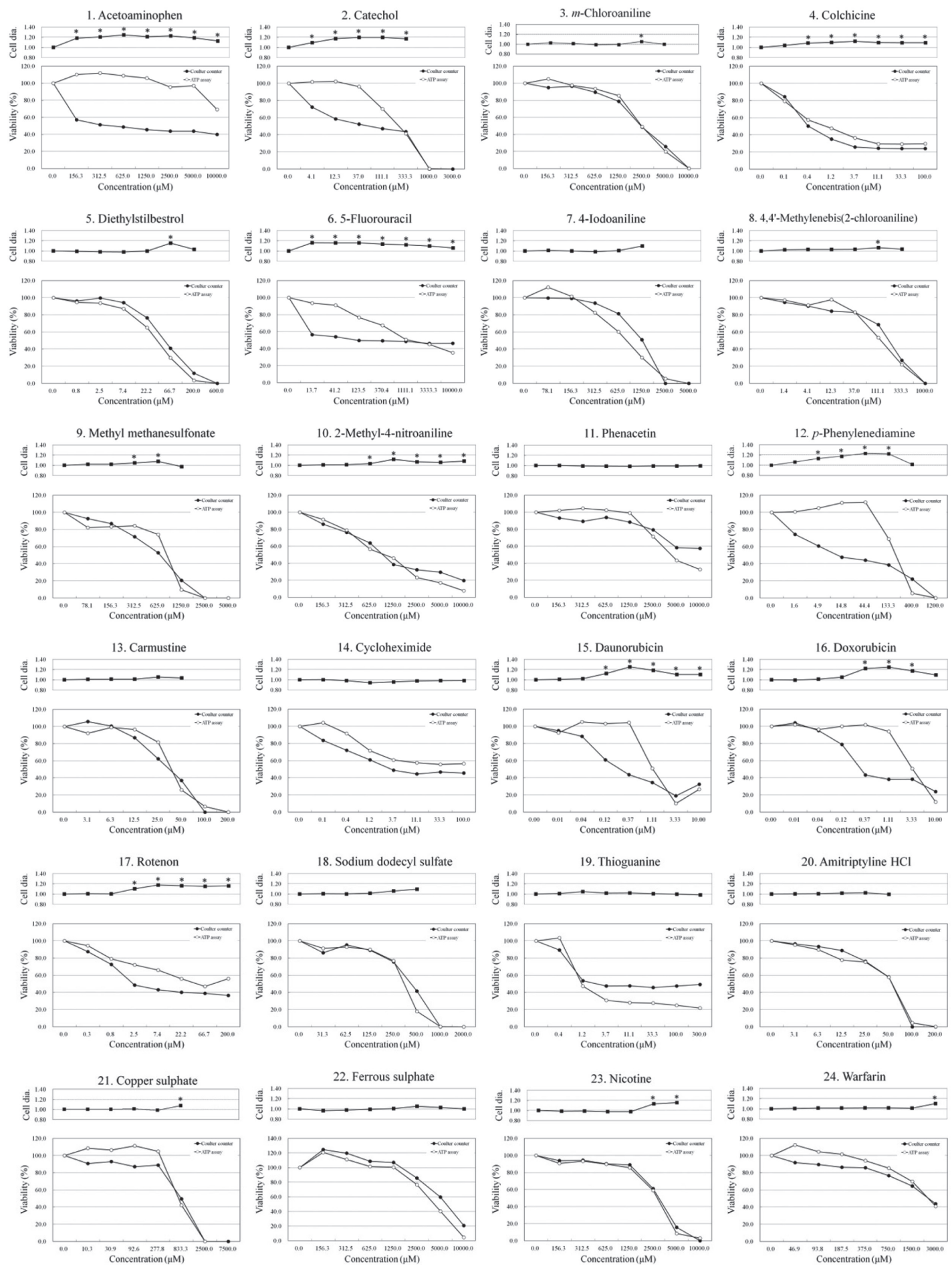

Fig. 1. Cell viability following treatment with 24 compounds, as measured using the adenosine triphosphate (ATP) assay and automatic cell counter. Cell diameters were measured using automatic cell counter. ${ }^{*}$, significant increase $(p<0.01)$ by Dunnett's multiple comparisons test. Cell dia, mean diameter of cells (ratio to control); cell viability, percentage of control (\%). $\circ$, ATP assay; •, automatic cell counter; P, precipitation of compounds. Cell diameter could not be measured in the presence of the following compounds due to strong cytotoxicity at high concentration: Catechol, $m$-chloroaniline, diethylstilbestrol, 4-iodoaniline, 4,4'-methylenebis(2-chloroaniline), methyl methanesulfonate, $p$-phenylenediamine, carmustine, amitriptyline $\mathrm{HCl}$, copper sulfate, and nicotine. 


\section{Cont.}

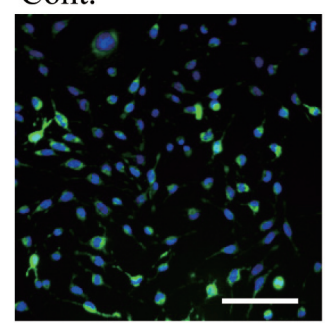

No.2 Catechol $111 \mu \mathrm{M}$

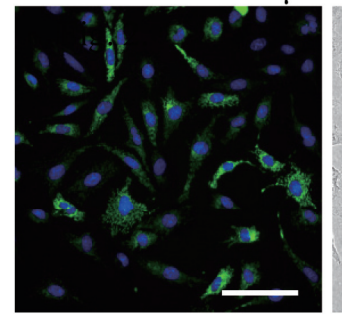

No.12 p-phenylenediamine $14.8 \mu \mathrm{M}$
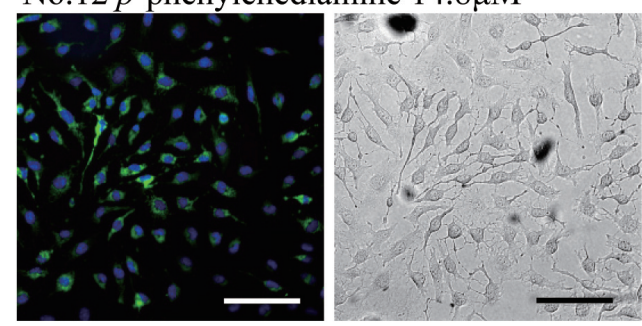

No.16 Doxorubicin $0.4 \mu \mathrm{M}$
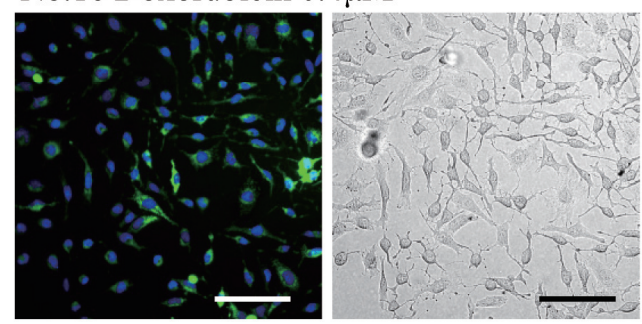

No.1 Acetaminophen $1250 \mu \mathrm{M}$

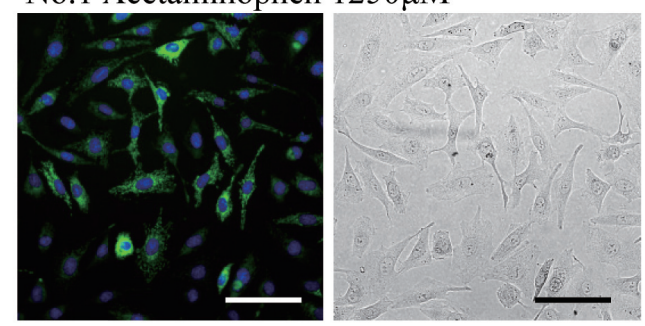

No.6 5-Fluorouracil $123.5 \mu \mathrm{M}$

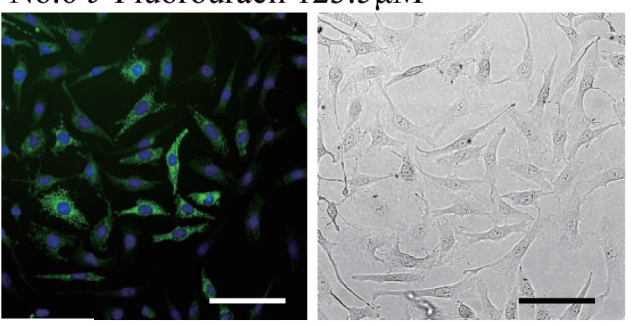

No.15 Daunorubicin $0.4 \mu \mathrm{M}$
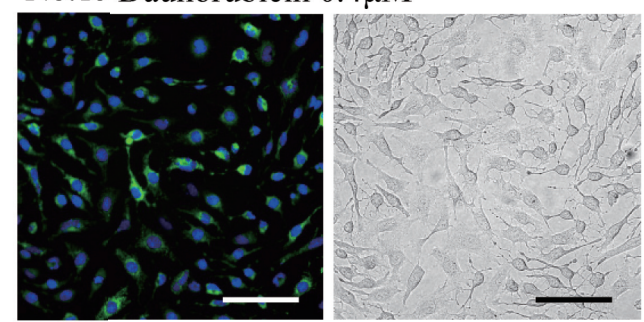

No.17 Rotenone $22.2 \mu \mathrm{M}$

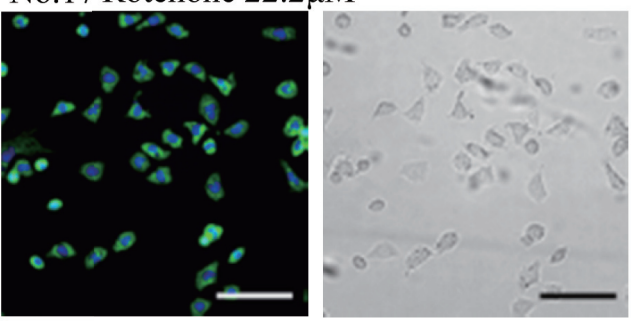

Fig. 2. Photograph of cells in which hypertrophy was induced, and ATP content per cell in the presence of 7 compounds. Left: Fluorescence images showing staining with MitoTracker green (green, mitochondria) and Hoechst 33342 (blue, nuclei). Right: Bright-field image. Scale bar: $100 \mu \mathrm{m}$.

compounds are daunorubicin and doxorubicin (Doerr et al., 1989), catechol (Matsushima et al., 1999), acetaminophen, 5-fluorouracil, and $p$-phenylenediamine (Ishidate et al., 1988). The remaining 1 compound, rotenone, was reported to increase the proportion of binucleated micronucleated cells and cause a delay in the cell cycle but does not increase the frequency of chromosome aberrations and sister-chromatid exchanges (Guadaño et al., 1998). Rotenone has also been shown to induce numerical aberration but not structural aberration (Corvi et al., 2008).
The cell cycle phases, which each of the 6 compounds arrest resulting in cytotoxicity, are as follows: daunorubicin, G2/M phase (Chikayama et al., 1998); doxorubicin, G2/M phase (Tyagi et al., 2002); acetaminophen, S phase (Wiger et al., 1997); 5-fluorouracil, S phase (Backus et al., 2000); p-phenylenediamine, G2 phase (Lee et al., 2015); and Rotenone, G2/M phase (Armstrong et al., 2001). Since there are few reports about the cell-cycle arrest by catechol, we estimated cell-cycle arrest phase of catechol to be $\mathrm{S}$ phase and G2/M phase by using simple 
Effect of chemically induced cellular hypertrophy on ATP assay

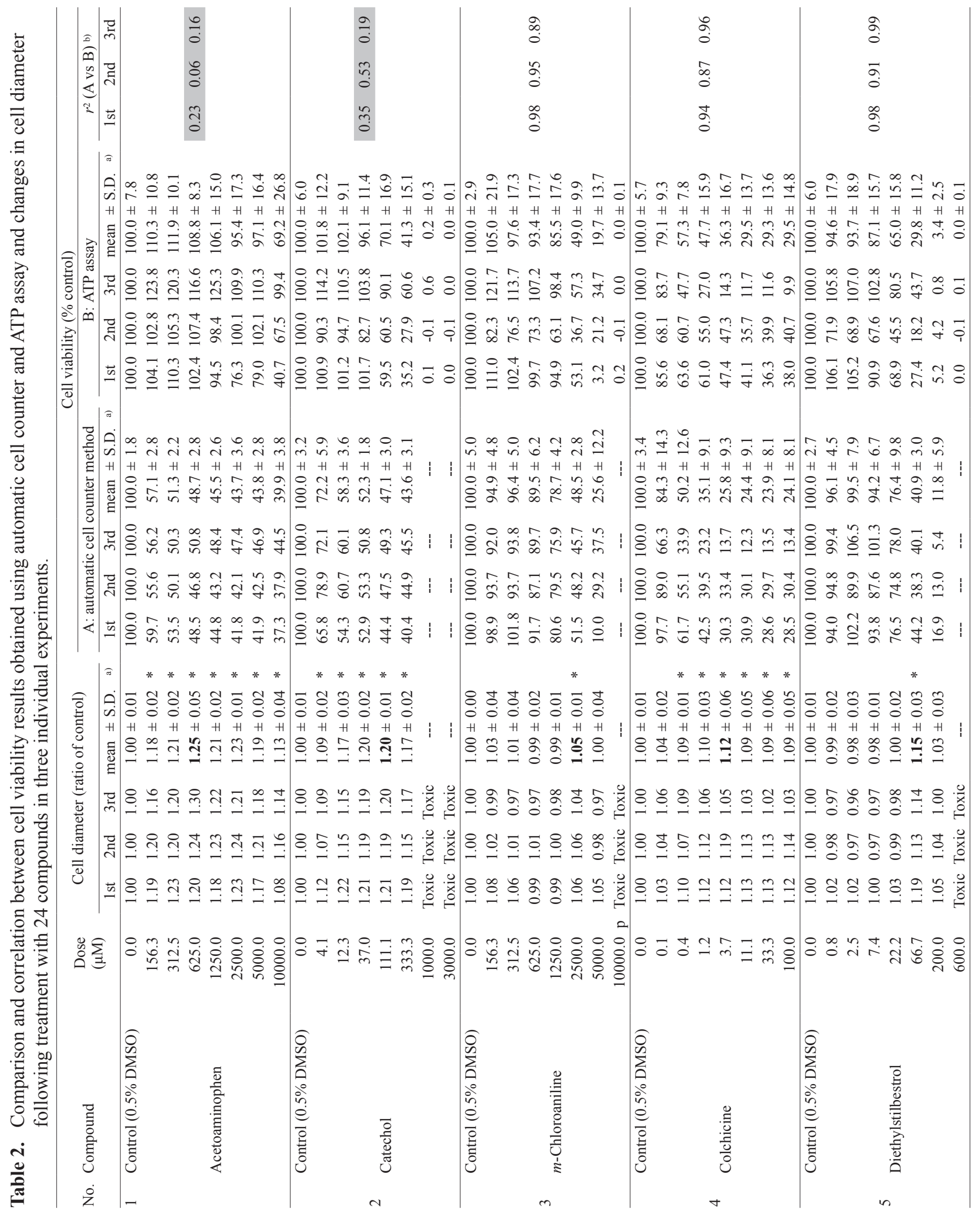


H. Tahara et al.

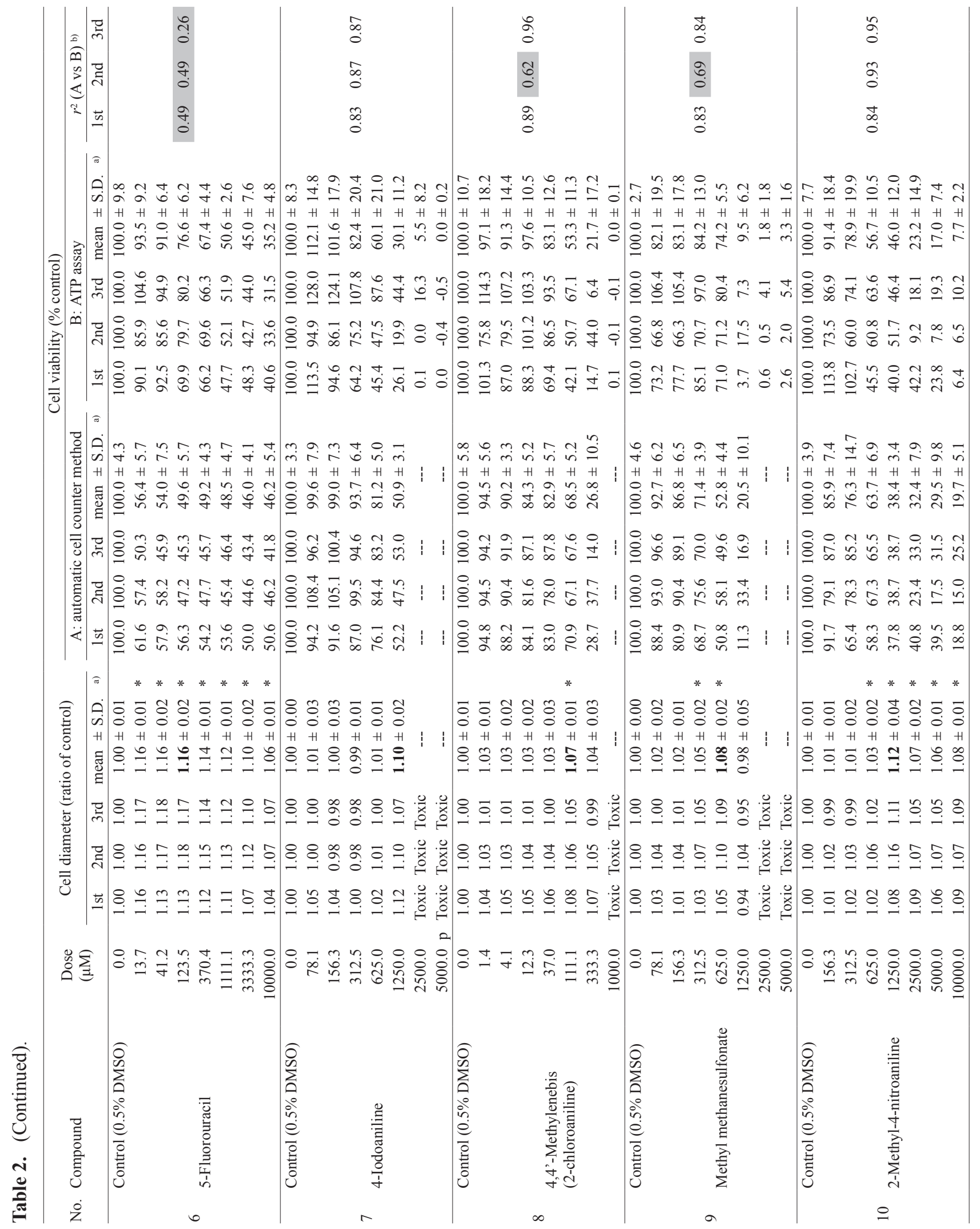

Vol. 42 No. 2 
Effect of chemically induced cellular hypertrophy on ATP assay

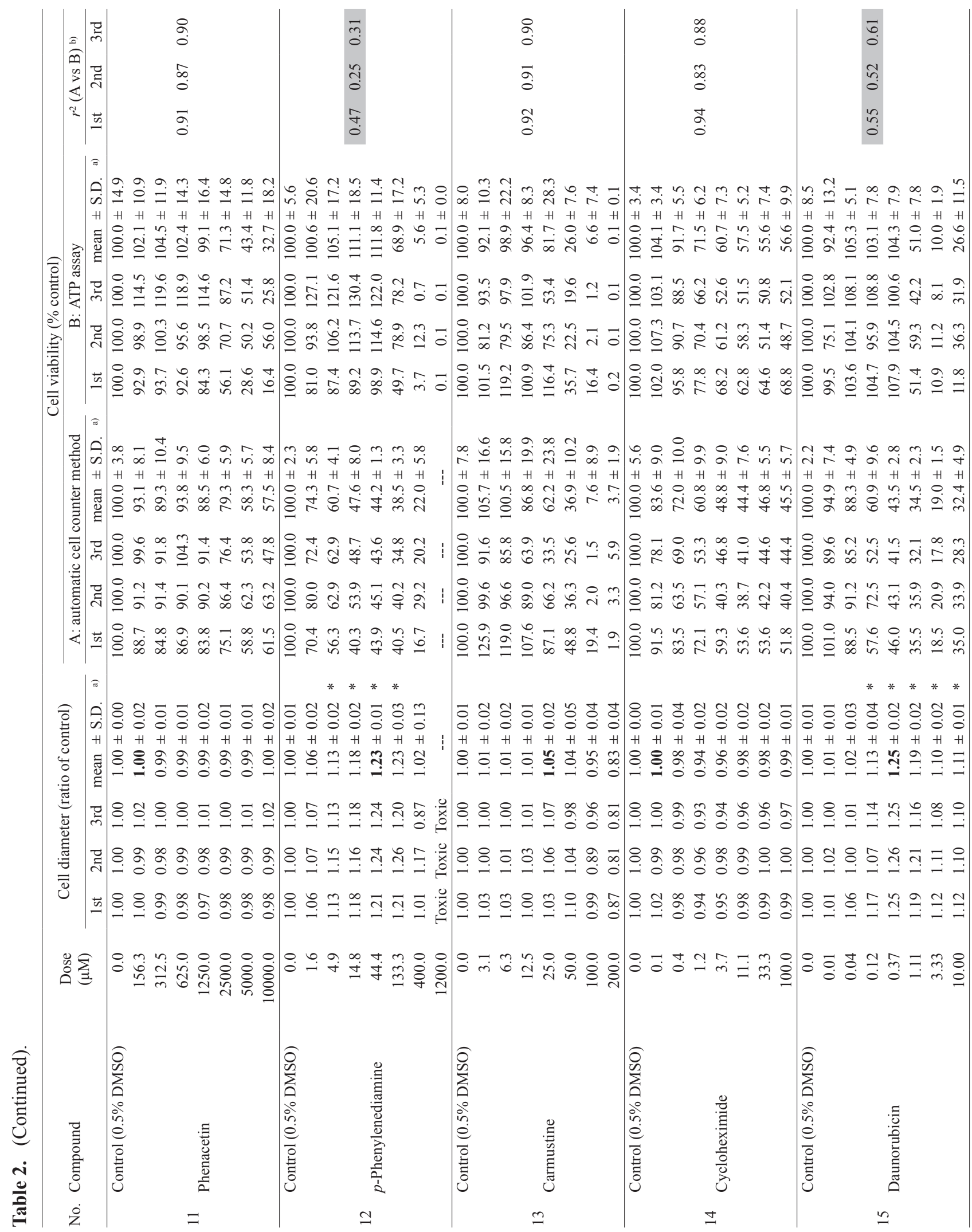


H. Tahara et al.

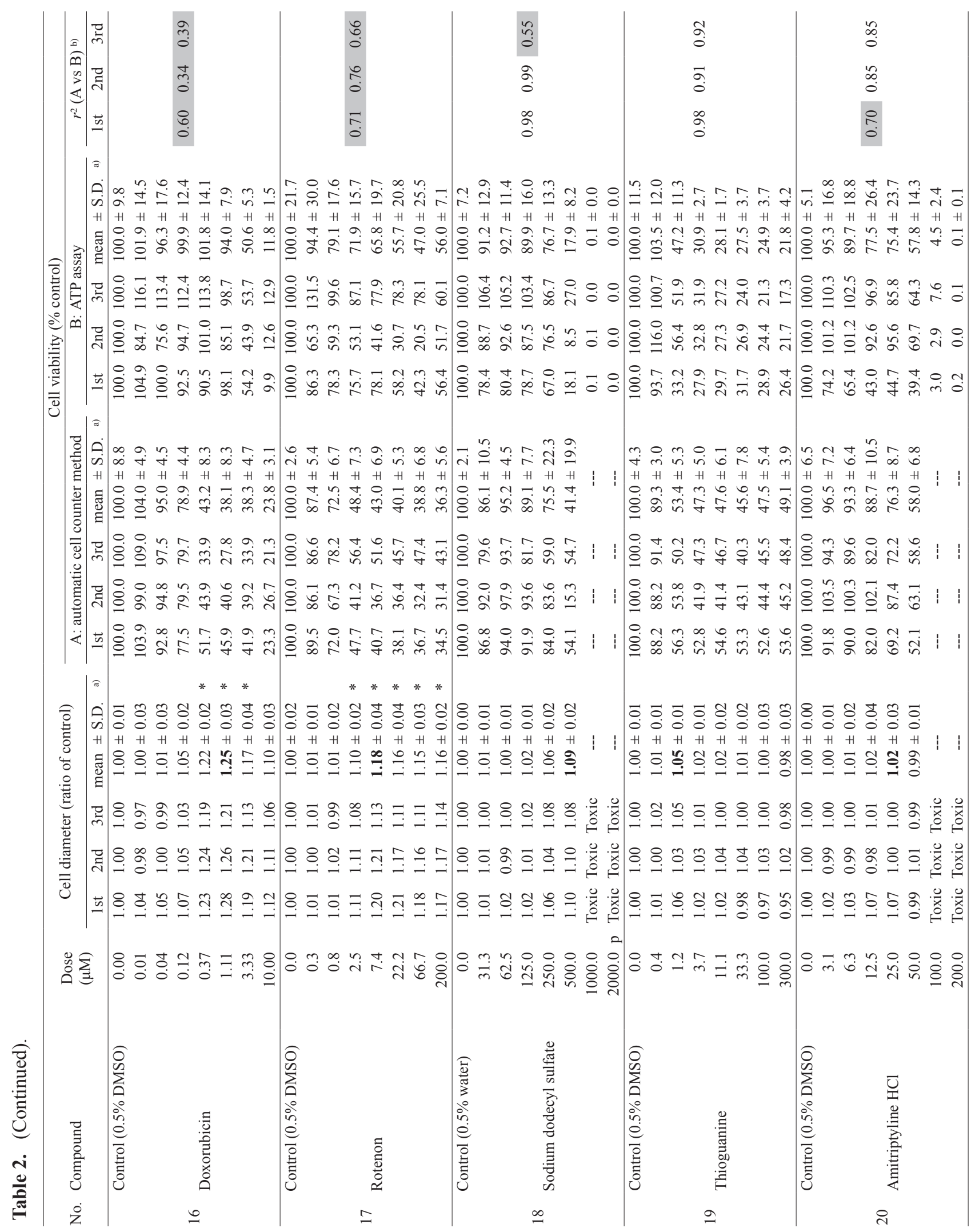

Vol. 42 No. 2 
Effect of chemically induced cellular hypertrophy on ATP assay

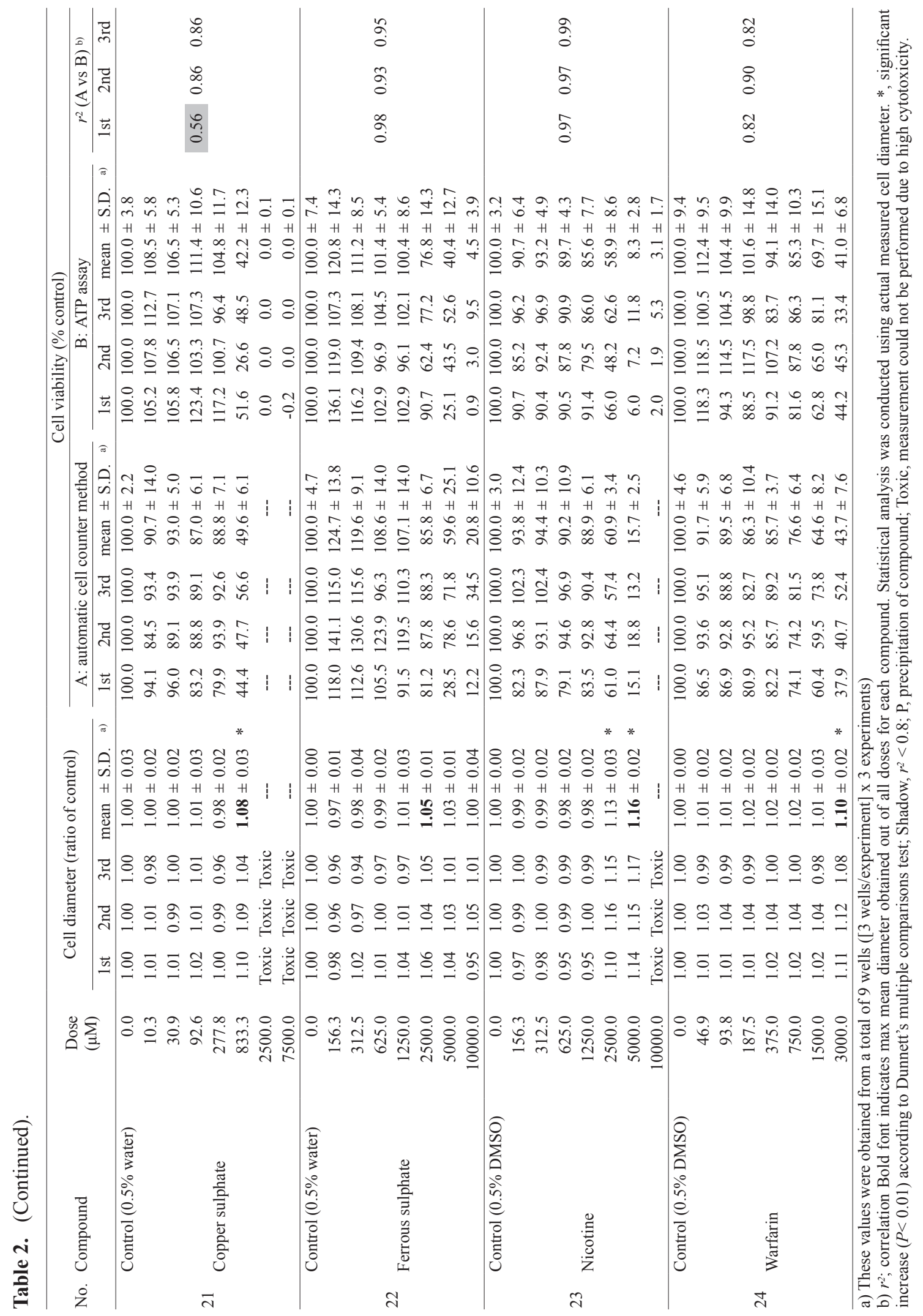

Vol. 42 No. 2 
H. Tahara et al.

Table 3. Mitochondrial area and whole cell area measured using image analyzer for 24 compounds.

\begin{tabular}{|c|c|c|c|c|c|c|c|c|c|c|c|c|c|}
\hline \multirow{2}{*}{\multicolumn{2}{|c|}{ No. Compound }} & \multirow{2}{*}{$\begin{array}{l}\text { Dose } \\
(\mu \mathrm{M})\end{array}$} & \multicolumn{2}{|l|}{$\begin{array}{l}\text { Cell area ratio } \\
\text { of control }(\%)\end{array}$} & \multirow{2}{*}{\multicolumn{2}{|c|}{$\begin{array}{l}\text { Mitochondrial } \\
\text { area ratio of } \\
\text { control }(\%)\end{array}$}} & \multicolumn{2}{|c|}{ No. Compound } & \multirow{2}{*}{$\begin{array}{l}\text { Dose } \\
(\mu \mathrm{M})\end{array}$} & \multicolumn{2}{|c|}{$\begin{array}{l}\text { Cell area ratio of } \\
\text { control }(\%)\end{array}$} & \multicolumn{2}{|l|}{$\begin{array}{l}\text { Mitochondrial } \\
\text { area ratio of } \\
\text { control (\%) }\end{array}$} \\
\hline & & & mean \pm S.D. & & & & & & & mean \pm S.D. & a) & mean \pm S.D. & a) \\
\hline \multirow{8}{*}{1} & Control (0.5\% DMSO) & 0.0 & $100.0 \pm 0.9$ & & $100.0 \pm 0.5$ & & & Control (0.5\% DMSO) & 0.0 & $100 \pm 5.0$ & & $100.0 \pm 1.0$ & \\
\hline & & 156.3 & $154.1 \pm 2.6$ & $*$ & $142.6 \pm 10$ & $*$ & & & 1.4 & $109.7 \pm 7.3$ & $*$ & $111.8 \pm 2.5$ & * \\
\hline & & 312.5 & $159.7 \pm 1.8$ & $*$ & $144.3 \pm 8.1$ & $*$ & & & 4.1 & $88.9 \pm 4.7$ & & $102.2 \pm 1.4$ & \\
\hline & & 625.0 & $169.4 \pm 2.3$ & $*$ & $158.4 \pm 6.2$ & $*$ & & & 12.3 & $91.1 \pm 5.2$ & & $99.5 \pm 2.8$ & \\
\hline & Acetaminophen & 1250.0 & $170.9 \pm 2.2$ & $*$ & $161.4 \pm 8.1$ & $*$ & 8 & 4,4'-Methylenebis & 37.0 & $94.5 \pm 3.6$ & & $94.1 \pm 2.8$ & \\
\hline & & 2500.0 & $167.8 \pm 1.9$ & $*$ & $163.4 \pm 5.6$ & $*$ & & $(2$-chloroaniline $)+$ & 111.1 & $93.7 \pm 4.4$ & & $90.5 \pm 3.3$ & \\
\hline & & 5000.0 & $154.8 \pm 3.9$ & * & $158.5 \pm 5.4$ & $*$ & & & 333.3 & $103.6 \pm 6.4$ & & $80.9 \pm 3.8$ & \\
\hline & & 10000.0 & $128.7 \pm 3.7$ & $*$ & $133.4 \pm 2.7$ & $*$ & & & 1000.0 & Toxic & & Toxic & \\
\hline \multirow{8}{*}{2} & Control (0.5\% DMSO) & 0.0 & $100.0 \pm 0.9$ & & $100.0 \pm 0.5$ & & & Control (0.5\% DMSO) & 0.0 & $100.0 \pm 5.0$ & & $100.0 \pm 1.0$ & \\
\hline & & 4.1 & $125.1 \pm 3.6$ & $*$ & $114.3 \pm 2.6$ & $*$ & & & 78.1 & $107.3 \pm 2.8$ & & $104.6 \pm 2.6$ & \\
\hline & & 12.3 & $148.7 \pm 0.8$ & * & $131.2 \pm 1.1$ & $*$ & & & 156.3 & $104.4 \pm 1.3$ & & $95.1 \pm 3.8$ & \\
\hline & & 37.0 & $160.9 \pm 1.9$ & $*$ & $146.1 \pm 2.7$ & $*$ & & & 312.5 & $104.3 \pm 1.3$ & & $89.9 \pm 5.6$ & \\
\hline & Catechol & 111.1 & $165.9 \pm 1.2$ & * & $142.7 \pm 0.8$ & $*$ & 9 & Methyl methanesulfonate & 625.0 & $100.9 \pm 7.1$ & & $78.8 \pm 4.9$ & \\
\hline & & 333.3 & $157.7 \pm 2.8$ & $*$ & $148.6 \pm 0.5$ & $*$ & & & 1250.0 & $95.2 \pm 0.6$ & & $73.6 \pm 6.7$ & \\
\hline & & 1000.0 & Toxic & & Toxic & & & & 2500.0 & Toxic & & Toxic & \\
\hline & & 3000.0 & Toxic & & Toxic & & & & 5000.0 & Toxic & & Toxic & \\
\hline \multirow{8}{*}{3} & Control (0.5\% DMSO) & 0.0 & $100.0 \pm 0.5$ & & $100.0 \pm 7.4$ & & & Control (0.5\% DMSO) & 0.0 & $100.0 \pm 0.6$ & & $100.0 \pm 2.2$ & \\
\hline & & 1562.5 & $106.3 \pm 1.8$ & & $97.6 \pm 7.2$ & & & & 156.3 & $101.0 \pm 2.8$ & & $91.8 \pm 2.3$ & \\
\hline & & 3125.0 & $104.6 \pm 1.0$ & & $99.9 \pm 7.1$ & & & & 312.5 & $102.5 \pm 4.9$ & & $89.1 \pm 2.7$ & \\
\hline & & 6250.0 & $103.9 \pm 1.3$ & & $100.1 \pm 7.6$ & & 10 & & 625.0 & $115.5 \pm 2.2$ & $*$ & $91.8 \pm 2.6$ & \\
\hline & $m$-Chloroaniline & 12500.0 & $98.5 \pm 2.3$ & & $99.8 \pm 8.0$ & & 10 & 2-Methyl-4-nitroaniline & 1250.0 & $122.7 \pm 3.4$ & $*$ & $97.1 \pm 2.6$ & \\
\hline & & 25000.0 & $90.0 \pm 3.9$ & & $111.8 \pm 8.8$ & & & & 2500.0 & $76.4 \pm 4.2$ & & $78.5 \pm 3.8$ & \\
\hline & & 50000.0 & $57.1 \pm 5.6$ & & $104.3 \pm 10.8$ & & & & 5000.0 & $67.7 \pm 1.7$ & & $103.9 \pm 3.5$ & \\
\hline & & 100000.0 & Toxic & & Toxic & & & & 10000.0 & $76.8 \pm 2.9$ & & $89.5 \pm 3.1$ & \\
\hline \multirow{8}{*}{4} & Control (0.5\% DMSO) & 0.0 & $100.0 \pm 0.9$ & & $100.0 \pm 0.5$ & & & Control (0.5\% DMSO) & 0.0 & $100.0 \pm 2.9$ & & $100.0 \pm 4.1$ & \\
\hline & & 0.1 & $89.6 \pm 2.1$ & & $96.1 \pm 0.9$ & & & & 156.3 & $97.6 \pm 4.4$ & & $87.5 \pm 3.2$ & \\
\hline & & 0.4 & $79.5 \pm 1.2$ & & $103.7 \pm 3.3$ & & & & 312.5 & $100.5 \pm 6.3$ & & $90.6 \pm 10.5$ & \\
\hline & & 1.2 & $72.7 \pm 0.9$ & & $101.2 \pm 2.1$ & & & & 625.0 & $96.2 \pm 4.2$ & & $79.1 \pm 8.8$ & \\
\hline & Colchicine & 3.7 & $65.7 \pm 1.4$ & & $97.8 \pm 3.2$ & & 11 & Phenacetin & 1250.0 & $102.4 \pm 1.8$ & & $82.0 \pm 6.9$ & \\
\hline & & 11.1 & $63.2 \pm 1.4$ & & $101.3 \pm 0.2$ & & & & 2500.0 & $101.9 \pm 4.8$ & & $84.3 \pm 3.9$ & \\
\hline & & 33.3 & $63.1 \pm 0.6$ & & $99.0 \pm 2.5$ & & & & 5000.0 & $98.6 \pm 3.1$ & & $85.6 \pm 9.5$ & \\
\hline & & 100.0 & $64.3 \pm 2.0$ & & $104.1 \pm 2.7$ & & & & 10000.0 & $99.3 \pm 1.0$ & & $91.8 \pm 3.6$ & \\
\hline \multirow{8}{*}{5} & Control (0.5\% DMSO) & 0.0 & $100.0 \pm 0.6$ & & $100.0 \pm 2.2$ & & & Control (0.5\% DMSO) & 0.0 & $100.0 \pm 2.8$ & & $100.0 \pm 5.2$ & \\
\hline & & 0.8 & $101.2 \pm 0.7$ & & $96.9 \pm 2.1$ & & & & 1.6 & $133.3 \pm 4.4$ & $*$ & $117.6 \pm 4.0$ & \\
\hline & & 2.5 & $96.6 \pm 8.9$ & & $93.6 \pm 4.7$ & & & & 4.9 & $156.4 \pm 1.0$ & $*$ & $128.9 \pm 2.3$ & $*$ \\
\hline & & 7.4 & $95.3 \pm 10.9$ & & $92.5 \pm 7.8$ & & & & 14.8 & $168.0 \pm 0.6$ & $*$ & $146.9 \pm 14$ & * \\
\hline & Diethylstilbestrol & 22.2 & $84.6 \pm 4.5$ & & $89.7 \pm 2.6$ & & 12 & $p$-Phenylenediamine & 44.4 & $169.3 \pm 2.3$ & $*$ & $148.3 \pm 6.7$ & * \\
\hline & & 66.7 & $97.6 \pm 5.5$ & & $109.0 \pm 5.1$ & & & & 133.3 & $153.0 \pm 0.6$ & $*$ & $167.5 \pm 3.0$ & * \\
\hline & & 200.0 & $47.9 \pm 3.5$ & & $81.4 \pm 1.3$ & & & & 400.0 & $59.9 \pm 1.3$ & & $178.4 \pm 1.2$ & * \\
\hline & & 600.0 & Toxic & & Toxic & & & & 1200.0 & Toxic & & Toxic & \\
\hline & Control (0.5\% DMSO) & 0.0 & $100.0 \pm 2.8$ & & $100.0 \pm 3.0$ & & & Control (0.5\% DMSO) & 0.0 & $100.0 \pm 3.9$ & & $100.0 \pm 9.3$ & \\
\hline & & 13.7 & $167.1 \pm 1.9$ & $*$ & $130.4 \pm 3.6$ & $*$ & & & 3.1 & $99.5 \pm 4.2$ & & $96.8 \pm 5.6$ & \\
\hline & & 41.2 & $176.9 \pm 1.6$ & $*$ & $147.9 \pm 4.7$ & $*$ & & & 6.3 & $97.0 \pm 4.1$ & & $96.6 \pm 6.5$ & \\
\hline & & 123.5 & $175.5 \pm 0.4$ & $*$ & $155.2 \pm 1.6$ & $*$ & & & 12.5 & $93.9 \pm 1.2$ & & $99.5 \pm 6.2$ & \\
\hline 6 & 5-Fluorouracil & 370.4 & $157.8 \pm 3.3$ & $*$ & $157.9 \pm 2.8$ & $*$ & 13 & Carmustine & 25.0 & $82.4 \pm 5.6$ & & $109.3 \pm 7.4$ & \\
\hline & & 1111.1 & $135.6 \pm 7.2$ & $*$ & $154.3 \pm 4.1$ & $*$ & & & 50.0 & $51.1 \pm 2.3$ & & $115.5 \pm 12.3$ & \\
\hline & & 3333.3 & $130.7 \pm 5.6$ & $*$ & $159.1 \pm 1.0$ & $*$ & & & 100.0 & $43.7 \pm 1.3$ & & $98.5 \pm 7.5$ & \\
\hline & & 10000.0 & $135.3 \pm 6.8$ & $*$ & $159.5 \pm 8.8$ & $*$ & & & 200.0 & Toxic & & Toxic & \\
\hline & Control (0.5\% DMSO) & 0.0 & $100.0 \pm 0.6$ & & $100.0 \pm 2.2$ & & & Control (0.5\% DMSO) & 0.0 & $100.0 \pm 2.0$ & & $100.0 \pm 2.6$ & \\
\hline & & 78.1 & $88.7 \pm 3.4$ & & $96.7 \pm 1.7$ & & & & 0.1 & $94.7 \pm 2.6$ & & $99.5 \pm 4.8$ & \\
\hline & & 156.3 & $82.9 \pm 1.2$ & & $95.1 \pm 1.6$ & & & & 0.4 & $83.0 \pm 2.1$ & & $94.2 \pm 5.3$ & \\
\hline 7 & & 312.5 & $79.3 \pm 2.6$ & & $95.5 \pm 2.8$ & & & & 1.2 & $77.2 \pm 2.7$ & & $92.2 \pm 8.5$ & \\
\hline 1 & 4-Iodoaniline & 625.0 & $75.3 \pm 1.6$ & & $98.3 \pm 1.3$ & & 14 & Cycloheximide & 3.7 & $74.5 \pm 1.6$ & & $83.5 \pm 5.6$ & \\
\hline & & 1250.0 & $70.3 \pm 0.4$ & & $93.2 \pm 2.2$ & & & & 11.1 & $75.6 \pm 1.4$ & & $65.2 \pm 4.7$ & \\
\hline & & 2500.0 & Toxic & & Toxic & & & & 33.3 & $73.5 \pm 2.7$ & & $70.0 \pm 3.7$ & \\
\hline & & 5000.0 & Toxic & & Toxic & & & & 100.0 & $65.9 \pm 1.2$ & & $61.2 \pm 3.6$ & \\
\hline
\end{tabular}

Vol. 42 No. 2 
Effect of chemically induced cellular hypertrophy on ATP assay

Table 3. (Continued).

\begin{tabular}{|c|c|c|c|c|c|c|c|c|c|c|c|c|c|}
\hline \multirow{2}{*}{\multicolumn{2}{|c|}{ No. Compound }} & \multirow{2}{*}{$\begin{array}{l}\text { Dose } \\
(\mu \mathrm{M})\end{array}$} & \multicolumn{2}{|c|}{$\begin{array}{l}\text { Cell area ratio } \\
\text { of control }(\%)\end{array}$} & \multicolumn{2}{|c|}{$\begin{array}{l}\text { Mitochondrial } \\
\text { area ratio of } \\
\text { control }(\%)\end{array}$} & \multicolumn{2}{|c|}{ No. Compound } & \multirow{2}{*}{$\begin{array}{l}\text { Dose } \\
(\mu \mathrm{M})\end{array}$} & \multicolumn{2}{|c|}{$\begin{array}{l}\text { Cell area ratio of } \\
\text { control }(\%)\end{array}$} & \multicolumn{2}{|l|}{$\begin{array}{l}\text { Mitochondrial } \\
\text { area ratio of } \\
\text { control }(\%)\end{array}$} \\
\hline & & & mean \pm S.D. & & mean \pm S.D. & & & & & mean \pm S.D. & a) & mean \pm S.D. & a) \\
\hline \multirow{8}{*}{15} & Control ( $0.5 \%$ DMSO) & 0.00 & $100.0 \pm 1.4$ & & $100.0 \pm 4.1$ & & & Control (0.5\% DMSO) & 0.0 & $100.0 \pm 3.7$ & & $100.0 \pm 12.5$ & \\
\hline & & 0.01 & $104.3 \pm 1.0$ & & $105.0 \pm 6.3$ & & & & 3.1 & $105.0 \pm 4.1$ & & $127.5 \pm 16.2$ & $*$ \\
\hline & & 0.04 & $109.7 \pm 0.5$ & $*$ & $115.2 \pm 4.9$ & $*$ & & & 6.3 & $106.0 \pm 3.0$ & & $142.6 \pm 15.8$ & $*$ \\
\hline & & 0.12 & $133.6 \pm 0.7$ & $*$ & $140.5 \pm 3.5$ & $*$ & 20 & & 12.5 & $106.9 \pm 4.1$ & $*$ & $164.4 \pm 16.6$ & $*$ \\
\hline & Daunorubicin & 0.37 & $178.8 \pm 1.8$ & $*$ & $208.8 \pm 6.9$ & $*$ & 20 & Amitriptyline $\mathrm{HCl}$ & 25.0 & $100.6 \pm 3.8$ & & $172.7 \pm 17.5$ & $*$ \\
\hline & & 1.11 & $98.7 \pm 3.9$ & & $161.8 \pm 1.1$ & $*$ & & & 50.0 & $73.3 \pm 2.3$ & & $151.4 \pm 15.6$ & $*$ \\
\hline & & 3.33 & $85.5 \pm 0.7$ & & $160.0 \pm 7.8$ & $*$ & & & 100.0 & Toxic & & Toxic & \\
\hline & & 10.00 & $80.6 \pm 1.7$ & & $129.9 \pm 1.4$ & $*$ & & & 200.0 & Toxic & & Toxic & \\
\hline \multirow{8}{*}{16} & Control (0.5\% DMSO) & 0.00 & $100.0 \pm 1.4$ & & $100.0 \pm 4.1$ & & & Control $(0.5 \%$ water $)$ & 0.0 & $100.0 \pm 1.6$ & & $100.0 \pm 4.5$ & \\
\hline & & 0.01 & $106.5 \pm 0.6$ & $*$ & $104.4 \pm 4.5$ & & & & 10.3 & $96.2 \pm 1.4$ & & $95.0 \pm 4.3$ & \\
\hline & & 0.04 & $107.7 \pm 1.5$ & $*$ & $105.6 \pm 1.8$ & & & & 30.9 & $94.8 \pm 2.0$ & & $98.5 \pm 4.2$ & \\
\hline & & 0.12 & $117.6 \pm 0.7$ & $*$ & $127.0 \pm 2.4$ & $*$ & & & 92.6 & $93.3 \pm 3.0$ & & $100.6 \pm 6.1$ & \\
\hline & Doxorubicin & 0.37 & $184.4 \pm 2.1$ & * & $185.5 \pm 1.0$ & $*$ & 21 & Copper sulfate & 277.8 & $94.9 \pm 3.4$ & & $105.2 \pm 7.5$ & \\
\hline & & 1.11 & $164.3 \pm 2.3$ & $*$ & $193.7 \pm 4.4$ & $*$ & & & 833.3 & $62.1 \pm 1.8$ & & $76.8 \pm 4.9$ & \\
\hline & & 3.33 & $103.6 \pm 1.4$ & & $156.7 \pm 2.3$ & $*$ & & & 2500.0 & Toxic & & Toxic & \\
\hline & & 10.00 & $89.2 \pm 1.5$ & & $156.1 \pm 6.3$ & $*$ & & & 7500.0 & Toxic & & Toxic & \\
\hline \multirow{8}{*}{17} & Control (0.5\% DMSO) & 0.0 & $100.0 \pm 1.6$ & & $100.0 \pm 4.5$ & & & Control $(0.5 \%$ water $)$ & 0.0 & $100.0 \pm 2.7$ & & $100.0 \pm 10.3$ & \\
\hline & & 0.3 & $93.5 \pm 0.6$ & & $101.9 \pm 1.2$ & & & & 156.3 & $90.8 \pm 2.5$ & & $93.3 \pm 15.4$ & \\
\hline & & 0.8 & $80.3 \pm 0.9$ & & $92.1 \pm 0.9$ & & & & 312.5 & $94.6 \pm 3.9$ & & $98.3 \pm 14.7$ & \\
\hline & & 2.5 & $109.8 \pm 2.1$ & $*$ & $133.0 \pm 0.8$ & $*$ & & & 625.0 & $96.9 \pm 3.2$ & & $99.8 \pm 5.9$ & \\
\hline & Rotenone & 7.4 & $108.9 \pm 1.9$ & * & $147.3 \pm 3.2$ & * & 22 & Ferrous sulfate & 1250.0 & $99.9 \pm 5.2$ & & $122.3 \pm 25.3$ & \\
\hline & & 22.2 & $84.3 \pm 1.5$ & & $136.0 \pm 5.7$ & $*$ & & & 2500.0 & $124.6 \pm 3.1$ & $*$ & $150.9 \pm 22.1$ & $*$ \\
\hline & & 66.7 & $68.2 \pm 0.8$ & & $120.7 \pm 2.7$ & $*$ & & & 5000.0 & $133.1 \pm 4.4$ & $*$ & $158.1 \pm 7.7$ & $*$ \\
\hline & & 200.0 & $60.4 \pm 0.7$ & & $113.0 \pm 2.7$ & $*$ & & & 10000.0 & Toxic & & Toxic & \\
\hline \multirow{8}{*}{18} & Control $(0.5 \%$ water $)$ & 0.0 & $100.0 \pm 2.9$ & & $100.0 \pm 4.1$ & & & Control (0.5\% DMSO) & 0.0 & $100.0 \pm 3.9$ & & $100.0 \pm 9.3$ & \\
\hline & & 31.3 & $92.1 \pm 3.9$ & & $82.1 \pm 4.3$ & & & & 156.3 & $98.0 \pm 1.9$ & & $88.4 \pm 3.1$ & \\
\hline & & 62.5 & $92.7 \pm 3.2$ & & $80.0 \pm 2.3$ & & & & 312.5 & $98.8 \pm 1.2$ & & $87.3 \pm 3.6$ & \\
\hline & & 125.0 & $98.1 \pm 1.0$ & & $81.6 \pm 4.1$ & & 23 & & 625.0 & $98.1 \pm 1.1$ & & $85.3 \pm 1.5$ & \\
\hline & Sodium dodecyl sulfate & 250.0 & $102.2 \pm 2.2$ & & $79.8 \pm 8.4$ & & 23 & Nicotine & 1250.0 & $96.1 \pm 0.9$ & & $83.2 \pm 3.0$ & \\
\hline & & 500.0 & $106.9 \pm 3.0$ & & $19.5 \pm 4.0$ & & & & 2500.0 & $89.0 \pm 1.4$ & & $90.3 \pm 4.1$ & \\
\hline & & 1000.0 & Toxic & & Toxic & & & & 5000.0 & Toxic & & Toxic & \\
\hline & & 2000.0 & Toxic & & Toxic & & & & 10000.0 & Toxic & & Toxic & \\
\hline \multirow{8}{*}{19} & Control (0.5\% DMSO) & 0.00 & $100.0 \pm 3.9$ & & $100.0 \pm 9.3$ & & & Control (0.5\% DMSO) & 0.0 & $100.0 \pm 2.9$ & & $100.0 \pm 4.1$ & \\
\hline & & 0.04 & $102.3 \pm 3.1$ & & $89.1 \pm 6.8$ & & & & 46.9 & $100.8 \pm 3.1$ & & $97.6 \pm 8.9$ & \\
\hline & & 0.12 & $103.3 \pm 7.5$ & & $88.8 \pm 8.6$ & & & & 93.8 & $101.7 \pm 4.5$ & & $94.9 \pm 3.3$ & \\
\hline & & 0.37 & $104.5 \pm 4.7$ & & $94.9 \pm 9.9$ & & & & 187.5 & $104.1 \pm 3.8$ & & $97.4 \pm 13.6$ & \\
\hline & Thioguanine & 1.11 & $87.6 \pm 4.4$ & & $94.3 \pm 9.3$ & & 24 & Warfarin & 375.0 & $100.7 \pm 4.2$ & & $81.5 \pm 11.4$ & \\
\hline & & 3.33 & $87.8 \pm 3.8$ & & $99.8 \pm 11.1$ & & & & 750.0 & $98.0 \pm 3.0$ & & $73.1 \pm 9.3$ & \\
\hline & & 10.00 & $92.0 \pm 4.9$ & & $96.3 \pm 7.6$ & & & & 1500.0 & $100.1 \pm 2.8$ & & $55.2 \pm 10.3$ & \\
\hline & & 30.00 & $91.3 \pm 3.7$ & & $96.9 \pm 11.1$ & & & & 3000.0 & $95.3 \pm 8.7$ & & $57.6 \pm 9.1$ & \\
\hline
\end{tabular}

a) These values were obtained from a total of 3 wells

*, significant increase $(P<0.01)$ by Dunnett's multiple comparisons test; Toxic, measurement could not be performed due to high cytotoxicity.

image analysis of cellular DNA content (data not shown).

There are a few reports concerning the chemically induced cell hypertrophy and increase in ATP content through cell cycle. Methotrexate (MTX) was shown to induce an increase in K562 cell size with S phase arrest (Raymakers et al., 1993). Synthetic purine, reversine, has been shown to induce cell cycle arrest in G2/M phase followed by an increase in the cell size in PC3 cells (Hsieh et al., 2007). DNA damage caused by anticancer drugs also elevates cellular ATP content (Neeman et al., 1990; de Jong et al., 1991; Berghmans et al., 1992). Oyama et al. (2011) reported that $\mathrm{H}_{2} \mathrm{O}_{2}$ and doxorubicin induced $\mathrm{G} 2 / \mathrm{M}$-cell cycle arrest with increased p21 expression in H9c2 cells, which was related to cellular hypertrophy. Some studies have also reported changes in cell size or intracellular ATP content over the course of the cell cycle in normal cells. Barberis et al. (2007) reported that from G1 phase to $M$ phase, the content of RNA and proteins increases exponentially, whereas the DNA content typically doubles with increasing cell size until the cell divides 
H. Tahara et al.

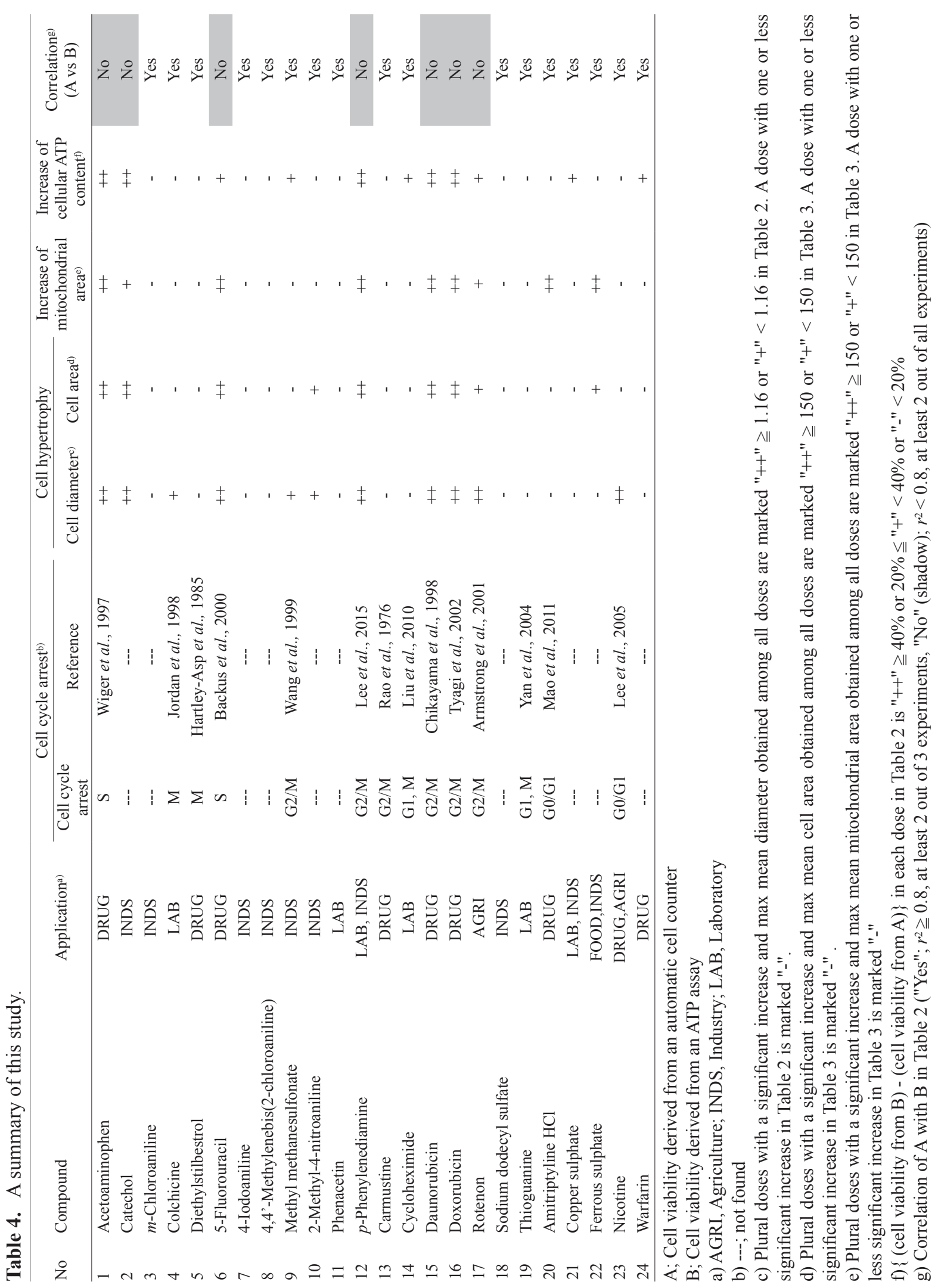

Vol. 42 No. 2 
Effect of chemically induced cellular hypertrophy on ATP assay

to generate two daughter cells. Marcussen and Larsen (1996) indicated that the cellular ATP concentration varies through the cell cycle, reaching a peak at G2/M phase and minimum at late G1/early S-phase. Recently, Chan et al. (2013) reported that low concentrations of drugs that arrest the cell cycle at $\mathrm{S}$ phase or $\mathrm{G} 2 / \mathrm{M}$ phase, induced repairable DNA damage, increase in cell size and amount of ATP per cell.

Since the size and ATP content per cell increases from G1 phase to G2/M phase through cell cycle, treating the cells with compounds that arrest the cell cycle at $\mathrm{S}$ phase or $\mathrm{G} 2 / \mathrm{M}$ phase, can lead to cell hypertrophy with increasing cellular ATP content.

In this study, the 7 compounds that arrested the cell cycle at $\mathrm{S}$ phase or $\mathrm{G} 2 / \mathrm{M}$ phase were all mutagens. Cell viability results of the ATP assay and those of direct cell counting after exposing the cells to these 7 compounds did not show good correlation. Carcinogens have been shown to induce nuclear enlargement in vitro (Finch et al., 1980; Westmoreland et al., 1994). These 7 compounds were also found to increase the size of the nucleus by using simple image analysis (data not shown). Therefore, we considered that the compounds, which cause DNA damage, like mutagens and carcinogens often induce cell hypertrophy and increase the cellular ATP content.

Furthermore, we tested whether other cell lines, $\mathrm{CHO}$, TK6 and 3T3 cells except for CHL cells are increased in cell size chemically by the compounds. Then, we confirmed that $\mathrm{CHO}$ and TK6 cell lines underwent an in cell size chemically, but $3 \mathrm{~T} 3$ cells were almost unchanged (data not shown). Although why 3T3 cells were not hypertrophied is unknown, in somatic cell division, it is believed that cellular constituents such as DNA, RNA, and protein are doubled during the $\mathrm{S}$ phase of the cell cycle; anticancer drugs used in this experiment arrest the cell cycle specifically at the stage of the late $\mathrm{S}$ phase and the G2/M stage where the cell size is increased with the increasing amount of cell constituents. Therefore, as a result, cell hypertrophy may be induced too, although all compounds that arrest the $\mathrm{S}$ phase and the G2/M stage do not always have this effect. Therefore, we expect that the size of cells that do not divide such as hepatocytes will not be increased even by these compounds.

In Table 4, we summarized the relation between cell cycle arrest and the factors clarified in this study. It was revealed that the correlation between the cell viability values derived from the cell number and values derived from the ATP assay was low when both the cell diameter and the mitochondrial area increased. Judging by the cell diameter and cell area, it appeared that such a phenomenon occurred during strong cellular hypertrophy. There are exceptions such as methyl methanesulfonate and carmustine, but compounds inducing the $\mathrm{S}$ phase and $\mathrm{G} 2 / \mathrm{M}$ arrest in the cell cycle tended to cause such a phenomenon.

In this study, we showed that the ATP assay is a highly accurate cytotoxicity test and its results correlate well with those of the automatic cell counter for compounds that do not induce cell hypertrophy. We also showed that the ATP assay underestimates cytotoxicity when compounds induce cell hypertrophy, and this is caused by an increase in intracellular ATP content resulting from an increase in the mitochondrial area. The ATP assay is therefore not suitable for assessing the cytotoxicity of cellular hypertrophy inducing compounds such as mutagens and carcinogens. It is therefore necessary to establish methods with high accuracy by including the evaluation of variables such as cell size.

\section{ACKNOWLEDGMENTS}

We thank Ms. Nanako Aihara, Ms. Misa Yaguchi, Ms. Maiko Takasaki and Ms. Sayaka Wanibuchi for technical assistance with the cell cultures. We also thank Mr. Taro Nakazawa (GE Healthcare) for technical support with the image analysis.

Conflict of interest---- The authors declare that there is no conflict of interest.

\section{REFERENCES}

Armstrong, J.S., Hornung, B., Lecane, P., Jones, D.P. and Knox, S.J. (2001): Rotenone-induced G2/M cell cycle arrest and apoptosis in a human B lymphoma cell line PW. Biochem. Biophys. Res. Commun., 289, 973-978.

Armstrong, M.J., Bean, C.L. and Galloway, S.M. (1992): A quantitative assessment of the cytotoxicity associated with chromosomal aberration detection in Chinese hamster ovary cells. Mutat. Res., 265, 45-60.

Augustine, N.H., Pasi, B.M. and Hill, H.R. (2007): Comparison of ATP production in whole blood and lymphocyte proliferation in response to phytohemagglutinin. J. Clin. Lab. Anal., 21, 265270.

Backus, H.H., Pinedo, H.M., Wouters, D., Kuiper, C.M., Jansen, G., van Groeningen, C.J. and Peters, G.J. (2000): Differences in the induction of DNA damage, cell cycle arrest, and cell death by 5-fluorouracil and antifolates. Oncol. Res., 12, 231-239.

Barberis, M., Klipp, E., Vanoni, M. and Alberghina, L. (2007): Cell size at S phase initiation: an emergent property of the G1/S network. PLoS Comput. Biol., 3, e64.

Bondesson, I., Ekwall, B., Hellberg, S., Romert, L., Stenberg, K. and Walum, E. (1989): MEIC--a new international multicenter project to evaluate the relevance to human toxicity of in vitro cytotoxicity tests. Cell Biol. Toxicol., 5, 331-347.

Berghmans, K., Ruiz-Cabello, J., Simpkins, H., Andrews, P.A. and 
Cohen, J.S. (1992): Increase in the ATP signal after treatment with cisplatin in two different cell lines studied by 31P NMR spectroscopy. Biochem. Biophys. Res. Commun., 183, 114-120.

Castaño, A. and Tarazona, J.V. (1994): ATP assay on cell monolayers as an index of cytotoxicity. Bull. Environ. Contam. Toxicol., $\mathbf{5 3}, 309-316$.

Chan, G.K., Kleinheinz, T.L., Peterson, D. and Moffat, J.G. (2013): A simple high-content cell cycle assay reveals frequent discrepancies between cell number and ATP and MTS proliferation assays. PLoS One, 8, e63583.

Chikayama, S., Kimura, S., Kobayashi, Y., Abe, T., Maekawa, T. and Kondo, M. (1998): Effects of daunorubicin on cell growth, cell cycle and induction of apoptosis in HL-60 cells. Haematologia (Budap)., 29, 115-121.

Cook, J.A. and Mitchell, J.B. (1989): Viability measurements in mammalian cell systems. Anal. Biochem., 179, 1-7.

Corvi, R., Albertini, S., Hartung, T., Hoffmann, S., Maurici, D., Pfuhler, S., van Benthem, J. and Vanparys, P. (2008): ECVAM retrospective validation of in vitro micronucleus test (MNT). Mutagenesis, 23, 271-283.

de Jong, S., Mulder, N.H., de Vries, E.G. and Robillard, G.T. (1991): NMR spectroscopy analysis of phosphorus metabolites and the effect of adriamycin on these metabolite levels in an adriamycin-sensitive and -resistant human small cell lung carcinoma cell line. Br. J. Cancer, 63, 205-212.

Doerr, C.L., Harrington-Brock, K. and Moore, M.M. (1989): Micronucleus, chromosome aberration, and small-colony TK mutant analysis to quantitate chromosomal damage in L5178Y mouse lymphoma cells. Mutat. Res., 222, 191-203.

Evans, S.M., Casartelli, A., Herreros, E., Minnick, D.T., Day, C., George, E. and Westmoreland, C. (2001): Development of a high throughput in vitro toxicity screen predictive of high acute in vivo toxic potential. Toxicol. In Vitro, 15, 579-584.

Finch, R.A., Evans, I.M. and Bosmann, H.B. (1980): Chemical carcinogen in vitro testing: a method for sizing cell nuclei in the nuclear enlargement assay. Toxicology, 15, 145-154.

Guadaño, A., González-Coloma, A. and de la Peña, E. (1998): Genotoxicity of the insecticide rotenone in cultured human lymphocytes. Mutat. Res., 414, 1-7.

Hartley-Asp, B., Deinum, J. and Wallin, M. (1985) Diethylstilbestrol induces metaphase arrest and inhibits microtubule assembly. Mutat Res., 143, 231-235.

Hsieh, T.C., Traganos, F., Darzynkiewicz, Z. and Wu, J.M. (2007): The 2,6-disubstituted purine reversine induces growth arrest and polyploidy in human cancer cells. Int. J. Oncol., 31, 1293-1300.

Hunter, E.M., Sutherland, L.A., Cree, I.A., Dewar, J.A., Preece, P.E., Wood, R.A., Linder, D. and Andreotti, P.E. (1993): Heterogeneity of chemosensitivity in human breast carcinoma: use of an adenosine triphosphate (ATP) chemiluminescence assay. Eur. J. Surg. Oncol., 19, 242-249.

Ishidate, M. Jr., Harnois, M.C. and Sofuni, T. (1988): A comparative analysis of data on the clastogenicity of 951 chemical substances tested in mammalian cell cultures. Mutat. Res., 195, 151-213.

Jordan, M.A. and Wilson, L. (1998): Microtubules and actin filaments: dynamic targets for cancer chemotherapy. Curr. Opin. Cell Biol., 10, 123-130.

Kemp, R.B., Meredith, R.W. and Gamble, S.H. (1985): Toxicity of commercial products on cells in suspension culture: a possible screen for the Draize eye irritation test. Food Chem. Toxicol., 23, 267-270.

Kuzmits, R., Aiginger, P., Müller, M.M., Steurer, G. and Linkesch, W. (1986): Assessment of the sensitivity of leukaemic cells to cytotoxic drugs by bioluminescence measurement of ATP in cultured cells. Clin. Sci. (Lond.), 71, 81-88.

Lee, H.J, Guo, H.Y., Lee, S.K., Jeon, B.H., Jun, C.D., Lee, S.K., Park, M.H. and Kim, E.C. (2005) Effects of nicotine on proliferation, cell cycle, and differentiation in immortalized and malignant oral keratinocytes. J. Oral Pathol. Med., 34, 436-443.

Lee, O.K., Cha, H.J., Lee, M.J., Lim, K.M., Jung, J.W., Ahn, K.J., An, I.S., An, S. and Bae, S. (2015): Implication of microRNA regulation in para-phenylenediamine-induced cell death and senescence in normal human hair dermal papilla cells. Mol. Med. Rep., 12, 921-936.

Liu, X., Yang, J.M., Zhang, S.S., Liu, X.Y. and Liu, D.X. (2010) Induction of cell cycle arrest at G1 and S phases and cAMP-dependent differentiation in $\mathrm{C} 6$ glioma by low concentration of cycloheximide. BMC Cancer, 10, 684.

Mao, X., Hou, T., Cao, B., Wang, W., Li, Z., Chen, S., Fei, M., Hurren, R., Gronda, M., Wu, D., Trudel, S. and Schimmer, A.D. (2011) The tricyclic antidepressant amitriptyline inhibits D-cyclin transactivation and induces myeloma cell apoptosis by inhibiting histone deacetylases: in vitro and in silico evidence. Mol. Pharmacol., 79, 672-680.

Matsushima, T., Hayashi, M., Matsuoka, A., Ishidate, M. Jr., Miura, K.F., Shimizu, H., Suzuki, Y., Morimoto, K., Ogura, H., Mure, K., Koshi, K. and Sofuni, T. (1999): Validation study of the in vitro micronucleus test in a Chinese hamster lung cell line (CHL/ IU). Mutagenesis, 14, 569-580.

Marcussen, M. and Larsen, P.J. (1996): Cell cycle-dependent regulation of cellular ATP concentration, and depolymerization of the interphase microtubular network induced by elevated cellular ATP concentration in whole fibroblasts. Cell Motil. Cytoskeleton, 35, 94-99.

Moon, S., Lee S., Kim H., Freitas-Junior, L.H., Kang, M., Ayong L. and Hansen, M.A. (2013): An image analysis algorithm for malaria parasite stage classification and viability quantification. PLoS One, 8, e61812. doi:10.1371/journal.pone.0061812.

Neeman, M., Eldar, H., Rushkin, E. and Degani, H. (1990): Chemotherapy-induced changes in the energetics of human breast cancer cells; 31P- and 13C-NMR studies. Biochim. Biophys. Acta., 1052, 255-263.

Okuda, H., Tsujimura, A., Yamamoto, K., Fukuhara, S., Nakayama, J., Kiuchi, H., Takao, T., Miyagawa, Y., Nonomura, N. and Okuyama, A. (2011): Morphologic and mitochondrial characterization of human spermatogenic cells dispersed in wet preparation for testicular sperm extraction: establishment of a microscopic diagram of developing human spermatogenic cells. Fertil. Steril., 95, 2665-2668.

Oyama, K., Takahashi, K. and Sakurai, K. (2011): Hydrogen peroxide induces cell cycle arrest in cardiomyoblast $\mathrm{H} 9 \mathrm{c} 2$ cells, which is related to hypertrophy. Biol. Pharm. Bull., 34, 501-506.

Petty, R.D., Sutherland, L.A., Hunter, E.M. and Cree, I.A. (1995): Comparison of MTT and ATP-based assays for the measurement of viable cell number. J. Biolumin. Chemilumin., 10, 29-34.

Rao, A.P. and Rao, P.N. (1976) The cause of G2-arrest in Chinese hamster ovary cells treated with anticancer drugs. J. Natl. Cancer Inst., 57, 1139-1143.

Raymakers, R., McGuire, J., Russell, C., Slocum, H., Malmberg, M. and Rustum, Y. (1993): Computerized image-analysis quantitation of heterogeneity of response in $\mathrm{k} 562$ human leukemia-cells after methotrexate exposure. Int. J. Oncol., 3, 299-304.

Sekhon, B.K., Roubin, R.H., Tan, A., Chan, W.K. and Sze, D.M. (2008): High-throughput screening platform for anticancer therapeutic drug cytotoxicity. Assay Drug Dev. Technol., 6, 711-721. 
Effect of chemically induced cellular hypertrophy on ATP assay

doi: 10.1089 /adt.2008.148

Tyagi, A.K., Singh, R.P., Agarwal, C., Chan, D.C. and Agarwal, R. (2002): Silibinin strongly synergizes human prostate carcinoma DU145 cells to doxorubicin-induced growth Inhibition, G2-M arrest, and apoptosis. Clin. Cancer Res., 8, 3512-3519.

Wang, X.W., Zhan, Q., Coursen, J.D., Khan, M.A., Kontny, H.U., Yu, L., Hollander, M.C., O'Connor, P.M., Fornace, A.J. Jr. and Harris, C.C. (1999) GADD45 induction of a G2/M cell cycle checkpoint. Proc. Natl. Acad. Sci. USA, 96, 3706-3711.

Westmoreland, C., Benford, D.J., Eales, L.J. and Grasso, P. (1994): Investigations into the mechanisms of carcinogen-induced nucle- ar enlargement in HeLa S3 cells in vitro. Toxicol In Vitro, 8, $1139-1150$.

Wiger, R., Finstad, H.S, Hongslo, J.K., Haug, K. and Holme, J.A. (1997): Paracetamol inhibits cell cycling and induces apoptosis in HL-60 cells. Pharmacol. Toxicol., 81, 285-293.

Yan, T., Desai, A.B., Jacobberger, J.W., Sramkoski, R.M,, Loh, T. and Kinsella, T.J. (2004) CHK1 and CHK2 are differentially involved in mismatch repair-mediated 6-thioguanine-induced cell cycle checkpoint responses. Mol. Cancer Ther., 3, 11471157. 